\title{
Hydrochemical Peculiarities of Bog Ecosystems in the North-Siberian Lowland
}

\author{
Tamara Efremova, Stanislav Efremov \\ V.N.Sukachev Institute of Forest, Siberian Branch of the Russian Academy of Sciences, \\ Academgorodok, Krasnoyarsk, Russia \\ E-mail:efr2@ksc.krasn.ru \\ Received April 8, 2010; revised May 20, 2010; accepted May 22, 2010
}

\begin{abstract}
Surface waters of eutrophic bogs (fens) in the North-Siberian (Taimyr) lowland are characterized by hydrocarbonate, sulfate as well as hydro carbonate-sulfate calcium-magnesium composition. They relate to the type of oxygen waters, mainly, to the class of neutral weakly alkaline and to the family of ultrafresh and fresh waters and to the kind of waters poor with dissolved organic matter. Natural hydrochemical background of bog ecosystems makes in heavy metals in the first approximation: $\mathrm{Co}-0.16, \mathrm{~Pb}-0.57, \mathrm{Ni}-4.67$ and $\mathrm{Cu}-5.94 \mathrm{mkg} / \mathrm{L}$. In most cases the surface waters are not polluted by heavy metals. Bog waters located in immediate closeness from Norilsk mining and smelting industrial complex are polluted by nickel at mid-level.
\end{abstract}

Keywords: Bogs, Hydrochemical Characteristics, Heavy Metals, Pollution

\section{Introduction}

The North-Siberian (Taimyr) lowland stretches out from the Yenisei river to the Khatanga gulf and borders in the north on the Byrranga mountains and in the south - on the Putoran mountains which is an extreme northern part of the Middle-Siberian plateau. The larger part of its area has a height less than $100 \mathrm{~m}$ above sea level (asl), and in the lesser one the hilly-glacial topography prevails up to the height $200-250 \mathrm{~m}$ asl. The lowland is rich in rivers and lakes of various origin (glacial-tectonic, glacial thermokarst, lagoon, floodplain one) and is characterized by a strong paludification. Cryogenic geological processes and such phenomena as thermokarst, solifluction, cryogenic heaving, cryogenic cracking, ice formation, ablation, subsurface erosion (erosive leakage) etc. which result in reconstruction of surface, also in soil and plant cover and in active paludification of the area are characteristic of natural complexes of the North-Siberian lowland. Thermokarst on frozen organogenic and porous mineral rocks connected with the destruction of ice in ground (segregation and deposit forming ice) is the result of formation of collapse shapes of topography. In combination with cryogenic heaving it results in that the surface of bog massifs obtains a complex morphostructural look. The different hypsometric hierarchy of small and middle forms of topography is clearly observed here.
Peat mounds (palsas) of different height with mineral core alternate with secondary pools and lakes which have sometimes peaty sometimes peaty-mineral or mineral bottoms.

According to bog zoning the studies were performed at the turn of two bog provinces: Middle Siberian province of tundra, larch open forests and flat-raised bogs as well as Middle Siberian province of northern and middle taiga forests and palsa mires $[1,2]$. Total feature for all peatlands of this type is an interchange of frost peat mounds 1-5 m high and melted depressions (bog hollows). Mounds are residual outcrops of very old peatlands from the warmer epoch of Quaternary period destroyed by erosion and thermokarst [3]. Bog hollows between mounds are contemporary bogs with a strongly pronounced peat accumulation process. The area of depressions, as a rule, considerably exceeds the extension of elevated areas. Mounds are usually covered by mossshrub and tree groups consisting of pine, larch and birch tree species; depressions are occupied by sedge-hypnum and sedge-sphagnum associations or pools. The water regime of bog hollows, as a rule heavily watered, has a running character. Run-off from the neighboring slopes of peat mounds proceeds in bog hollows. The flow of subpermafrost waters which accelerates degradation of permafrost in mounds is also observed here. Thickness of peat enveloping bedding of bog hollows makes from 0.8 
to 3 meters. Low mire peat deposits prevail in assigned bog provinces, it means the sedge and hypnum deposits take about $70 \%$ but sphagnum ones take approximately $30 \%$.

Wide development of sulfide-copper-nickel mineralization is a characteristic feature of natural-territorial complexes in the Priyeniseisky trans-polar region [4]. Unique copper-nickel fields of the Norilsk ore region are related to the Priyeniseisky megablock. Alkaline, alkaline-basite, then basite and hyper basite-basite as well as toleite (trapps), alkaline-hyper basite, also kimberlite products of magmatism which are the certain chains in the lateral and age series of magmatism and endogenic ore formation are developed within this megablock successively (from the west to the east).

Natural waters, having a contact with different chemical variations of rocks, inevitably gain a specific composition which sufficiently shows in time and space the initial natural mosaic structure of conditions for their formation. In addition to natural factors the hydrogeological and hydrochemical situation in the studied region is determined also by emission of sulfur and heavy metals into the atmosphere by enterprises of non-ferrous metallurgy of the Norilsk mining and smelting industrial complex. Aerosol technogenic (mancaused) emissions are differently accumulated in the catchment area depending on their type, remoteness from the emission source, also on component and aggregate composition of technogenic fluxes, geomorphology of the territory, prevailing wind rose, weather, season and other factors. The processes of intralandscape migration of chemical elements are also developed ambiguously. Geomorphologically subordinate peat and bog ecosystems can play the positive role in accumulation and in "damping" of ecologically hazardous technogenic fluxes. Peatlands are a combined geochemical barrier-mechanic, oxygen, biogenic and sorption one where many chemical elements are accumulated [5]. However the buffer "capacity" of hydromorphic complexes has a certain stability threshold outside of which the degradation of the system itself starts. Therefore under high technogenic loads on environment the problem of protection of natural water resources becomes one of the most important. Meanwhile, bogs in the North-Siberian lowland area are poorly studied from the hydrological point of view.

The aim of this paper was the following: in comparison with waters of rivers and deep lakes of glacial- tectonic genesis a) to determine chemical composition of waters in bog hydrographic network and on this base to make up their classification; b) to analyze the amount of water soluble $\mathrm{Cu}, \mathrm{Ni}, \mathrm{Co}, \mathrm{Pb}$ which show the element composition of sulfide ores; c) to assess the pollution level of surface waters by heavy metals and sulfur.

\section{Objects and Methods of Study}

Paludified basins of Bol'shoi Avam, Norilskaya, Rybnaya, Omuntakh, Ambarnaya rivers, also "hanging" bogs in Khaeralakh mountains, raised peatlands in vicinity of Kayerkan town-Burovoye lake, the route Alykel'Vologochan as well as the cape Bludnyi (in the region of the lake Melkoye) were covered by studies (Figure 1). The first-hand points for water sampling were: organogenic, secondary lakes of thermokarst origin; transit waters of overlying bogs which are accumulated in pools (sized less than $1 \mathrm{ha}$ ) on slope (hanging) peatlands; fissure bog waters of frost peat mounds; bog waters of lakes at the different heights toward the foot of a large peat mound (Table 1). Water samples were taken simultaneously in rivers, in the lake Melkoye which is of glacialtectonic origin and in the waterfall "Krasnyye kamni (Red stones)".

Determination of $\mathrm{pH}$, water soluble carbon, calcium, magnesium, chlorine and hydrogen carbonate was performed according to the instruction [6]. Potassium, sodium, water soluble heavy metals and sulfur were determined by methodical instructions [7-9]. Geochemical classification of waters was made according to [10]. The following taxonomic levels were segregated: groups, types, classes, families, genera, and kinds of waters.

\section{Chemical Composition and Classification of Surface Waters}

Surface waters of the North- Siberian lowland relate to the group of cold and weak thermal as well as to the type of oxygen waters. By alkaline- acidic conditions they, mainly, correspond to the class of neutral and weak alkaline waters (Table 2). This is the class of waters $(\mathrm{pH}$ 6.5-8.5) to which the majority of natural waters of the land relates. In the water phase of peatlands the medium reaction makes, mainly, $\mathrm{pH} 6,4-7,4$ similar to forest fens

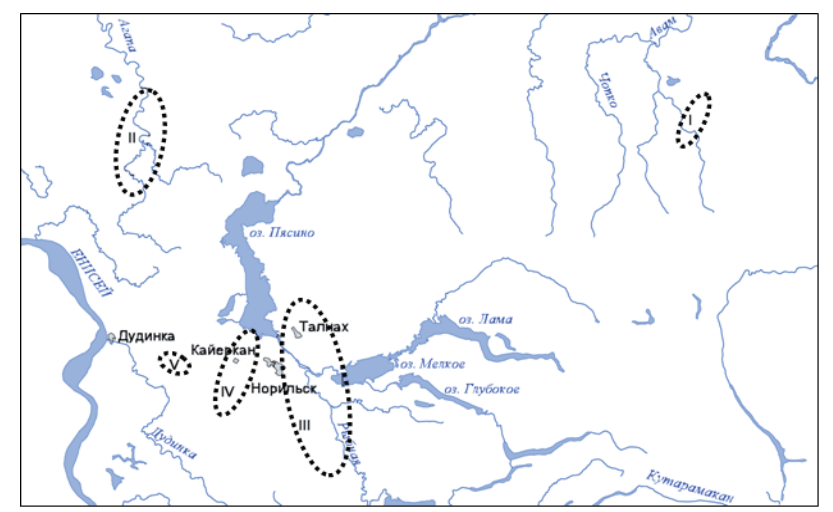

Figure 1. Chart of study regions. 
Table 1. Regions and water sampling points of bog, river, waterfall and glacial-tectonic lakes in the North-Siberian lowland (the phase of mean water).

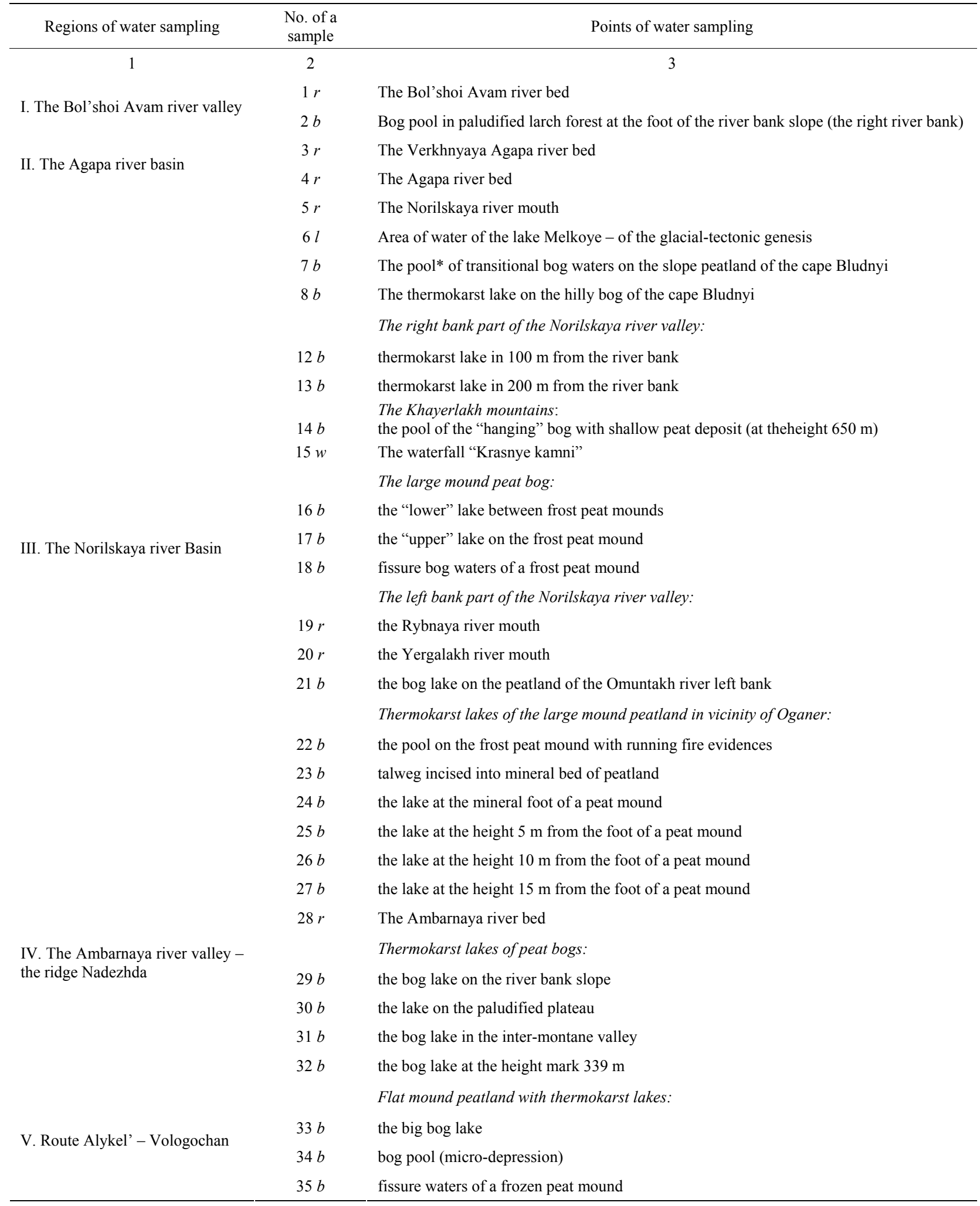

Legend: $r$-river, $b$ - bog, $l$-lake, $w$-waterfall, $\left.{ }^{*}\right)$ pool-water area less than 1 ha 
of boreal forest zone. Waters of other classes are met more seldom. So, the strong-acid waters ( $\mathrm{pH}$ 3.6-4.0) were found in bog lakes in suburb of Oganer, Kayerkan town (samples $22 b, 30 b$ ), in fissure water of flat- hilly peatland in the neighborhood of Alykel' airport (35 b). Acidity of such water in nature derives usually from oxidation of disulfides what results in $\mathrm{H}_{2} \mathrm{SO}_{4}$ [10]. However the formation of sulfuric acid in the study region can also have an anthropogenic nature which is connected with emissions of sulfur oxides by enterprises of non- ferrous metallurgy of the Norilsk mining and smelting industrial complex. Heavily alkaline waters with $\mathrm{pH}$ 9-10 are also found in vicinity of Oganer suburb. This is a talweg incised into mineral bed of peat land $(23 \mathrm{~b})$ and a bog lake on mineral foot of a large peat mound (24b). Heavily alkaline medium is determined most likely by the contact with saline bed of relict genesis. It was shown that in Mesozoic the Yenisei-Khatangskaya depression was flooded by a shallow-water sea which was resulted in salification of subaqueous grounds [11]. Ionic com-

Table 2. Chemical composition of waters in bogs, rivers, waterfall and lakes of glacial- tectonic origin in the North- Siberian (the Taimyr) lowland (the mean water phase)

\begin{tabular}{|c|c|c|c|c|c|c|c|c|c|c|}
\hline \multirow{2}{*}{$\begin{array}{c}\text { No.of } \\
\text { water } \\
\text { sample* }\end{array}$} & \multirow{2}{*}{$\begin{array}{l}\text { Sum of ions, } \\
\mathrm{mg} / \mathrm{L}\end{array}$} & \multirow{2}{*}{$\mathrm{pH}$} & \multirow{2}{*}{$\begin{array}{c}\mathrm{C}, \\
\mathrm{mg} / \mathrm{L}\end{array}$} & \multicolumn{3}{|c|}{ Anions, mg/L } & \multicolumn{4}{|c|}{ Cations, mg/L } \\
\hline & & & & $\mathrm{HCO}_{3}^{-}$ & $\mathrm{SO}_{4}^{2-}$ & $\mathrm{Cl}^{-}$ & $\mathrm{Ca}^{2+}$ & $\mathrm{Mg}^{2+}$ & $\mathrm{Na}^{+}$ & $\mathrm{K}^{+}$ \\
\hline 1 & 2 & 3 & 4 & 5 & 6 & 7 & 8 & 9 & 10 & 11 \\
\hline \multicolumn{11}{|c|}{ Waters of rivers, waterfall and the lake of glacial- tectonic genesis } \\
\hline $1 r$ & 54,06 & 7,1 & 2,76 & 35,38 & 3,94 & 2,91 & 7,12 & 3,32 & 1,20 & 0,19 \\
\hline $3 r$ & 33,40 & 7,1 & 2,53 & 17,08 & 3,98 & 3,78 & 4,75 & 2,86 & 0,70 & 0,25 \\
\hline $4 r$ & 41,69 & 6,9 & 2,41 & 14,64 & 12,38 & 4,94 & 5,54 & 3,32 & 0,62 & 0,24 \\
\hline $5 r$ & 56,51 & 7,2 & 1,56 & 23,18 & 12,43 & 5,81 & 10,30 & 2,85 & 1,80 & 0,14 \\
\hline $19 r$ & 48,66 & 6,9 & 2,56 & 17,08 & 12,82 & 5,52 & 8,70 & 2,85 & 1,59 & 0,10 \\
\hline $20 r$ & 119,77 & 7,3 & 2,07 & 41,48 & 42,00 & 4,36 & 22,96 & 6,17 & 2,59 & 0,21 \\
\hline $28 r$ & 189,13 & 7,0 & 0,62 & 78,08 & 64,99 & 2,61 & 26,14 & 13,78 & 3,18 & 0,34 \\
\hline $15 w$ & 51,16 & 7,1 & 1,12 & 23,18 & 10,99 & 4,07 & 7,92 & 3,80 & 1,02 & 0,18 \\
\hline $6 l$ & 47,83 & 6,4 & 2,91 & 17,08 & 12,38 & 5,81 & 7,92 & 2,85 & 1,69 & 0,10 \\
\hline \multicolumn{11}{|c|}{ Bog waters } \\
\hline $2 b$ & 52,68 & 6,9 & 3,76 & 29,28 & 5,66 & 4,94 & 7,92 & 3,33 & 1,50 & 0,05 \\
\hline $7 b$ & 136,91 & 7,0 & 4,51 & 71,98 & 25,39 & 4,65 & 23,76 & 8,55 & 2,45 & 0,13 \\
\hline $8 b$ & 60,56 & 6,5 & 2,41 & 17,08 & 25,63 & 3,20 & 10,30 & 3,80 & 0,50 & 0,05 \\
\hline $12 b$ & 189,73 & 7,6 & 1,42 & 122,0 & 22,51 & 3,49 & 22,17 & 13,31 & 6,20 & 0,05 \\
\hline $13 b$ & 112,33 & 7,4 & 2,87 & 63,44 & 18,38 & 3,20 & 15,84 & 7,60 & 3,42 & 0,45 \\
\hline $14 b$ & 48,06 & 6,5 & 2,18 & 17,08 & 16,27 & 3,20 & 6,34 & 4,27 & 0,88 & 0,06 \\
\hline $16 b$ & 101,15 & 7,4 & 0,62 & 63,44 & 10,46 & 4,07 & 13,46 & 7,12 & 2,12 & 0,48 \\
\hline $17 b$ & 200,34 & 7,3 & 1,16 & 134,20 & 18,10 & 2,61 & 25,34 & 14,73 & 3,40 & 1,96 \\
\hline $18 b$ & 40,39 & 6,4 & 1,16 & 4,88 & 21,89 & 2,61 & 6,33 & 3,33 & 1,22 & 0,13 \\
\hline $21 b$ & 229,70 & 6,9 & 2,72 & 35,38 & 132,29 & 3,20 & 39,60 & 14,25 & 4,60 & 0,38 \\
\hline $22 b$ & 84,96 & 3,6 & 3,13 & No & 58,94 & 3,78 & 13,46 & 7,13 & 0,60 & 1,05 \\
\hline $23 b$ & 187,43 & 9,1 & 1,39 & 76,49 & 58,94 & 5,81 & 26,53 & 14,49 & 5,12 & 0,05 \\
\hline $24 b$ & 927,34 & 10,0 & 1,36 & 225,7 & 345,60 & 74,4 & 53,06 & 20,74 & 178,80 & 29,0 \\
\hline $25 b$ & 289,83 & 7,4 & 1,57 & 53,68 & 158,21 & 6,97 & 42,77 & 21,86 & 4,50 & 1,84 \\
\hline $26 b$ & 336,74 & 7,2 & 2,15 & 23,18 & 214,75 & 5,81 & 55,44 & 28,51 & 6,80 & 2,25 \\
\hline $27 b$ & 226,72 & 6,1 & 2,54 & 10,98 & 140,74 & 5,81 & 34,05 & 13,78 & 1,36 & 20,00 \\
\hline $29 b$ & 183,02 & 7,5 & 0,62 & 96,38 & 40,08 & 2,61 & 25,34 & 12,36 & 5,60 & 0,65 \\
\hline $30 \mathrm{~b}$ & 61,84 & 4,1 & 1,60 & No & 44,88 & 2,91 & 12,67 & 4,22 & 0,80 & 0,66 \\
\hline
\end{tabular}


position of bog waters shows just this. In the lake near the mineral foot of the large mound peatland Oganer we have found a considerable amount of sodium $179 \mathrm{mg} / \mathrm{L}$ as compared to $0.2-6.8 \mathrm{mg} / \mathrm{L}$ in other study objects. This higher sodium amount is, for sure, the result of exchange sorption of calcium waters with sodium in rocks of marine origin. Here the increased amount of $\mathrm{Cl}^{-}$ion $74.4 \mathrm{mg} / \mathrm{L}$ was also found which is not great $(2.6-12.2 \mathrm{mg} / \mathrm{L})$ in surface water of Taimyr lowland what is typical of rivers, lakes and bogs of northern areas. Chlorine is as a main anion in seas and salty lakes. At the water contact with saline mineral rocks the chlorine is easily leached and is accumulated in the lake.

In mineralization degree (i.e. sum of dissolved ions) the studied surface waters relate to the ultra fresh $(<100$ $\mathrm{mg} / \mathrm{L})$ and fresh (100-1000 mg/L) water family. Water of almost all rivers, of the lake Melkoye and waterfall "Krasnye kamni" is ultra fresh one. Fresh water is only in rivers Ambarnaya and Yergalakh (189.1 and 119.8 $\mathrm{mg} / \mathrm{L}$, respectively). Such results agree with the characteristics of river waters in Siberia: water mineralization in the Yenisei river makes 53.8, in the $\mathrm{Ob}^{\prime}$ river-76.6, in the Lena river $-84.6 \mathrm{mg} / \mathrm{L}$, in the Angara river mouth it is $90-100 \mathrm{mg} / \mathrm{L}$ [3]. On the average, waters in studied bogs are more mineralized: $41.7 \%$ of them relate to the ultra fresh and 58,3\% - to fresh waters (101.2-927.3 mg/L, respectively). It is determined by removal of chemical elements from catchment area and by accumulation in hypsometrically lower topography elements. Most mineralized are waters of organogenic lakes in suburb of Oganer which is located near sources of technogenic emissions.

All water categories, including bog waters, contain the small amount of water soluble carbon-0.62-4.51 mg/L and relate to the kind of water which is poor with soluble organic substance. Such a peculiarity is determined, in our opinion, by two conditions: a) transformation of plant debris proceeds in tundra slowly; b) the humification products being formed in neutral and weak alkaline water are easily fixed by cations, forming the organomineral complexes, then they coagulate and precipitate.

Ionic composition of waters defines their important geochemical peculiarities and is assumed as a basis of their dividing into the kinds-the smallest taxon of water classification by Perel'man, Kasimov. The quality of the performed chemical water analysis is confirmed by the value of the definition error: the difference between the sum of anions and cations does not exceed 5\% in all the cases (Table 3). Water systematization to the kinds was carried out according to prevailing ions and according to the correlation between them $[12,13]$. In the MiddleSiberian lowland the hydrocarbonate and sulfate waters are noted according to dominating anion $\mathrm{HCO}^{-}, \mathrm{Cl}^{-}$, $\mathrm{SO}_{4}{ }^{2-}$ at its amount more than $25 \% \mathrm{mg}$-equv/L from the anion sum. In the case of exceeding $25 \%$ by two anions the combined waters are noted-hydrocarbonate-sulfate and sulfate- hydrocarbonate ones (Table 3). Depending on domination of $\mathrm{Ca}^{2+}, \mathrm{Mg}^{2+}, \mathrm{Na}^{+}$the waters are divided into calcium-magnesium, magnesium- calcium and sodium ones.

The sulfate $(39 \%)$ and hydrocarbonate $(35 \%)$ waters prevail in bog ecosystems, but the combined waters hydrocarbonate-sulfate and sulfate-hydrocarbonate ones dominate in rivers. Sulfate amount in river water approaches to the average $\mathrm{SO}_{4}{ }^{2-}$ concentration in the waters of the land as a whole which makes $12 \mathrm{mg} / \mathrm{L}$ [14]. Bog waters contain sulfates much more, as a rule. The waters of lakes of the large mound peatland Oganer are most rich in $\mathrm{SO}_{4}{ }^{2-}$ ion, its amount makes $141-345 \mathrm{mg} / \mathrm{L} \mathrm{(24} \mathrm{b-}$ $27 b)$ which is located in the epicenter of technogenic emissions of the mining and smelting industrial complex "Norilsk nickel". Exceeding relative to the average index for the waters of the land as a whole achieves here an order and more.

Hydrocarbonate waters are characteristic of both river and bog waters, but mostly of last ones. The amount of $\mathrm{HCO}_{3}{ }^{-}$ion varies widely within $1-226 \mathrm{mg} / \mathrm{L}$. In acid bog waters ( $\mathrm{pH} 3.6-4.1)$ the hydrocarbonate anion is not met. Calcium (4.0-55.4 $\mathrm{mg} / \mathrm{L})$ and magnesium (0,90-28,5 $\mathrm{mg} / \mathrm{L})$ are dominating cations. The ratio $\mathrm{Ca}^{2+}: \mathrm{Mg}^{2+}$ makes, mainly, 2:1 in waters being studied varying in the mouth of the Norilskaya, Rybnaya and Yergalakh rivers up to 3-3.7. Such results agree as a whole with the ratio of dominating cations in fresh natural water [13].

Hydrocarbonate calcium-magnesium waters of bogs, rivers and lakes in cold humid regions are zonal. Sulfatehydrocarbonate, hydrocarbonate-sulfate and sulfate waters show most likely the regional specificity determined by sulfide fields of ores. Such waters are typical of the rivers Agapa, Norilskaya, Rybnaya, Yergalakh, Ambarnaya, of the lake Melkoye and some bog ecosystems (14 $b$, 23-24 $b, 29 b$ ). Sulfate waters are inherent only in bogs. In tundra landscapes this phenomenon is azonal [10] since geographically they correspond to a greater extent to central and southern parts of the steppe zone. Sulfate ultrafresh and fresh waters of bog ecosystems relate to different classes in their alkaline-acidic properties: neutral and weak alkaline $(\mathrm{pH}$ 6.5-8.5) as well as weak acidic ones ( $\mathrm{pH}$ 3 4-6.5). This relation to different classes was used for preliminary assessment of contribution of potential $\mathrm{SO}_{4}{ }^{2-}$ sources to the water environment.

In our opinion, neutral and weak alkaline sulfate waters of bog ecosystems reflect to a greater extent the subalkaline trend of intra-chamber differentiation of theTalnakh-Norilsk sulfide massif. This trend is due to in tensive alkalinization of initial hyperbasite-basite melt [4]. At the contactwith alkalis the underground sulfide waters are neutralized. Being connected with surface waters in regional deep faults they enrich waters with sulfates: the Norilsk ore region is located under extreme conditions of 
Table 3. Classification of surface waters by ionic composition and assessment of definition error at chemical analysis

\begin{tabular}{|c|c|c|c|c|c|c|c|}
\hline \multirow{3}{*}{$\begin{array}{c}\text { No.of water } \\
\text { sample* }\end{array}$} & $\begin{array}{c}\sum \text { of anions } \\
\left(\sum a\right)\end{array}$ & $\begin{array}{c}\sum \text { of cations } \\
\left(\sum \mathrm{c}\right)\end{array}$ & \multirow{3}{*}{$\begin{array}{c}\text { Definition } \\
\text { error**, \% }\end{array}$} & \multicolumn{3}{|c|}{ mg-equiv/Lof the anion sum, $\%$} & \multirow{3}{*}{$\begin{array}{c}\text { Water kind } \\
8\end{array}$} \\
\hline & \multicolumn{2}{|c|}{ mg-equiv/L } & & $\mathrm{HCO}_{3}^{-}$ & $\mathrm{Cl}^{-}$ & $\mathrm{SO}_{4}{ }^{2-}$ & \\
\hline & 2 & 3 & & 5 & 6 & 7 & \\
\hline \multicolumn{8}{|c|}{ Waters of rivers, waterfall and lakes of glacial- tectonic genesis } \\
\hline $1 r$ & 0,745 & 0,690 & 3,8 & 77,85 & 11,14 & 11,0 & $\mathrm{C}^{\mathrm{MgCa}}$ \\
\hline $3 r$ & 0,471 & 0,513 & 4,3 & 59,44 & 22,9 & 17,62 & $\mathrm{C}^{\mathrm{CaMg}}$ \\
\hline $4 r$ & 0,639 & 0,587 & 4,2 & 37,55 & 22,06 & 40,37 & $\mathrm{CS}^{\mathrm{CaMg}}$ \\
\hline $5 r$ & 0,805 & 0,857 & 3,1 & 47,20 & 20,62 & 32,20 & $\mathrm{SC}^{\mathrm{MgCa}}$ \\
\hline $19 r$ & 0,704 & 0,745 & 2,8 & 39,77 & 22,30 & 37,93 & $\mathrm{SC}^{\mathrm{MgCa}}$ \\
\hline $20 r$ & 1,679 & 1,781 & 2,9 & 40,50 & 7,38 & 52,11 & $\mathrm{SC}^{\mathrm{MgCa}}$ \\
\hline $28 r$ & 2,708 & 2,602 & 2,0 & 47,26 & 2,73 & 50,0 & $\mathrm{CS}^{\mathrm{CaMg}}$ \\
\hline $15 w$ & 0,725 & 0,762 & 2,5 & 52,27 & 15,95 & 31,49 & $\mathrm{SC}^{\mathrm{MgCa}}$ \\
\hline $6 l$ & 0,704 & 0,709 & 0,04 & 39,77 & 23,58 & 36,64 & $\mathrm{SC}^{\mathrm{MgCa}}$ \\
\hline \multicolumn{8}{|c|}{ Bog waters } \\
\hline $2 b$ & 0,739 & 0,739 & 0,0 & 64,95 & 19,08 & 15,96 & $\mathrm{C}^{\mathrm{MgCa}}$ \\
\hline $7 b$ & 1,841 & 2,01 & 4,4 & 64,09 & 7,17 & 28,73 & $\mathrm{SC}^{\mathrm{MgCa}}$ \\
\hline $8 b$ & 0,905 & 0,855 & 2,8 & 30,93 & 10,05 & 59,0 & $\mathrm{SC}^{\mathrm{MgCa}}$ \\
\hline $12 b$ & 2,568 & 2,488 & 1,6 & 77,88 & 3,85 & 18,26 & $\mathrm{C}^{\mathrm{Ca} \mathrm{Mg}}$ \\
\hline $13 b$ & 1,514 & 1,586 & 2,3 & 68,69 & 6,01 & 25,30 & $\mathrm{C}^{\mathrm{MgCa}}$ \\
\hline $14 b$ & 0,710 & 0,712 & 0,14 & 39,44 & 12,68 & 47,75 & $\mathrm{CS}^{\mathrm{CaMg}}$ \\
\hline 1 & 2 & 3 & 4 & 5 & 6 & 7 & 8 \\
\hline $16 \mathrm{~b}$ & 1,374 & 1,371 & 0,0 & 75,69 & 8,44 & 15,14 & $\mathrm{CMg} \mathrm{Ca}$ \\
\hline $17 \mathrm{~b}$ & 2,651 & 2,693 & 0,8 & 83,02 & 2,8 & 14,22 & $\mathrm{CMg} \mathrm{Ca}$ \\
\hline $18 \mathrm{~b}$ & 0,610 & 0,650 & 3,2 & 13,11 & 12,13 & 74,75 & $\mathrm{~S} \mathrm{Mg} \mathrm{Ca}$ \\
\hline $21 \mathrm{~b}$ & 3,427 & 3,378 & 0,7 & 16,92 & 2,65 & 80,42 & $\mathrm{~S} \mathrm{Mg} \mathrm{Ca}$ \\
\hline $22 \mathrm{~b}$ & 1,336 & 1,32 & 0,6 & no & 8,08 & 91,96 & $\mathrm{~S} \mathrm{Mg} \mathrm{Ca}$ \\
\hline $23 \mathrm{~b}$ & 2,704 & 2,783 & 1,4 & 46,23 & 6,14 & 45,41 & $\mathrm{SCMg} \mathrm{Ca}$ \\
\hline $24 \mathrm{~b}$ & 13,0 & 12,90 & 0,4 & 28,46 & 16,15 & 55,38 & $\mathrm{CSNa}$ \\
\hline $25 \mathrm{~b}$ & 4,37 & 4,202 & 2,0 & 20,13 & 4,55 & 75,28 & $\mathrm{~S} \mathrm{Mg} \mathrm{Ca}$ \\
\hline $26 \mathrm{~b}$ & 5,02 & 5,50 & 4,5 & 7,57 & 3,31 & 89,04 & $\mathrm{~S} \mathrm{Mg} \mathrm{Ca}$ \\
\hline $27 \mathrm{~b}$ & 3,278 & 3,423 & 2,2 & 5,49 & 5,06 & 89,44 & $\mathrm{~S} \mathrm{Mg} \mathrm{Ca}$ \\
\hline $29 \mathrm{~b}$ & 2,489 & 2,557 & 1,3 & 63,48 & 2,97 & 33,54 & $\mathrm{CS} \mathrm{Ca} \mathrm{Mg}$ \\
\hline $30 \mathrm{~b}$ & 1,018 & 1,042 & 1,2 & no & 8,15 & 91,84 & $\mathrm{~S} \mathrm{Mg} \mathrm{Ca}$ \\
\hline $31 \mathrm{~b}$ & 2,952 & 2,936 & 0,3 & 63,68 & 11,82 & 24,49 & $\mathrm{CMg} \mathrm{Ca}$ \\
\hline $32 \mathrm{~b}$ & 3,106 & 3,052 & 0,9 & 72,44 & 2,67 & 24,88 & $\mathrm{CMg} \mathrm{Ca}$ \\
\hline $33 \mathrm{~b}$ & 0,625 & 0,645 & 1,6 & 60,8 & 23,84 & 15,36 & $\mathrm{CMg} \mathrm{Ca}$ \\
\hline $34 \mathrm{~b}$ & 0,326 & 0,324 & 0,3 & 4,91 & 22,39 & 72,70 & $\mathrm{~S} \mathrm{Mg} \mathrm{Ca}$ \\
\hline $35 \mathrm{~b}$ & 0,274 & 0,287 & 2,3 & no & 22,26 & 77,34 & $\mathrm{~S} \mathrm{Mg} \mathrm{Ca}$ \\
\hline
\end{tabular}

stress relief from the rift-genic (fissure- and ditch-like) structures [3]. Neutral and weak alkaline sulfate waters were found in bog lakes of the Omuntakh river left bank and in those ones of the large mound peatland in Oganer suburb $(21 b, 25 b, 26 b)$.
We assume that formation of acid sulfate waters in bog ecosystems is directly connected with the impact of technogenic sulfur oxide fluxes by enterprises of the Norilsk mining and smelting industrial complex. Acid sulfate waters $(\mathrm{pH} 3.6-6.1)$ were found in vicinity of 
towns Talnakh, Kayerkan, Oganer suburb and the route Alykel'-Vologachan to the west from Norilsk city (the samples $18 b, 22 b, 30 b, 34 b, 35 b$ ). Ultrafresh and fresh bog waters, not saturated practically with all mineral compounds, have a great dissolving ability but the deficit of bases does not enable them to neutralize fully the annual setting out $\mathrm{SO}_{3}$ amount. An active acidification points to the instability of water phase of bogs to technogenic emissions because of lack of mechanisms which support it in stable regime (the low mineralization, high dissolving ability, deficit of bases).

Therefore the transformation of hydrocarbonatic and hydrocarbonate-sulfate waters into sulfate ones is entirely appropriate for typical geochemically subordinated bog landscapes. It is not improbable that acid sulfate waters of bog ecosystems can be the result of natural processes. In frozen regions the sulfide fields have an oxidation zone of sulfate type with formation of sulfuric acid and easily dissolved sulfates of $\mathrm{Fe}, \mathrm{Cu}, \mathrm{Zn}$ and other metals [10]. This version is indirectly supported by the highest Fe amount just in heavy acid (1000-740 mkg/L) sulfate waters in relation to other objects (361-3.6 $\mathrm{mkg} / \mathrm{L})$.

\section{Amount of Water Soluble Forms of Heavy metals and Assessment of Pollution Level of Surface Waters}

Equally with sulfur the solid emissions of $\mathrm{Ni}, \mathrm{Cu}, \mathrm{Co}, \mathrm{Pb}$ are present in aerotechnogenic fluxes of the Norilsk mining and smelting industrial complex. Amount of water soluble forms of heavy metals in surface waters of Taimyr lowland greatly varies both in water categories (the bog, river and lake waters) and in study regions (Tables 4 and 5 ).

The low concentration of metals is noted in the "Krasnye kamni" waterfall, also in rivers and lakes located to the north, the north-east and the east from Norilsk city rivers Verkhnyaya Agapa and Agapa, the mouth of the Norilskaya river, Bol'shoy Avam and the lake Melkoye. The total amount of heavy metals in ultrafresh and fresh waters of rivers and lakes with neutral and alkaline medium reaction doesn't almost exceed $10 \mathrm{mkg} / \mathrm{L}$. In the vicinity of Talnakh town there is also relatively little $\mathrm{Cu}$, $\mathrm{Ni}, \mathrm{Co}, \mathrm{Pb}-3-14 \mathrm{mkg} / \mathrm{L}$ in surface waters, somewhat more of them $-5-19 \mathrm{mkg} / \mathrm{L}$ there is in the KayerkanVologochan region, mainly, in waters of bog ecosystems. As an exception here the bog lake with heavy acidic sulfate waters (the left bank of the Ambarnaya river) is where the sum of water soluble metals is enlarged up to $150 \mathrm{mkg} / \mathrm{L}$. However, the highest concentration of heavy metals is revealed in bog ecosystems of the Oganer suburb. In thermokarst lakes, formed at different heights of the large mound peatland, the sum amount of heavy met- als ranges from 140 to $800 \mathrm{mkg} / \mathrm{L}$. Their maximum is found in waters of peatland gone by rapid fire.

Based on such an analysis the surface waters were divided into three groups by the amount of accumulated heavy metals: 1) river and lake waters, 2) bog waters with a low amount of $\mathrm{Ni}, \mathrm{Cu}, \mathrm{Co}$ and $\mathrm{Pb}$ which, to a first approximation, we consider as a natural background and 3 ) bog waters which are at maximum enriched by heavy metals.

As it follows from the Table 5, the sum amount of heavy metals in waters of rivers and lakes of Taimyr lowland makes $2.5-10.4 \mathrm{mkg} / \mathrm{L}$. The average amount of $\mathrm{Co}$ is $0.07, \mathrm{~Pb}-0.59, \mathrm{Ni}-1.02, \mathrm{Cu}-3.33 \mathrm{mkg} / \mathrm{L}$. It was stated that the average concentration of heavy metals in river and fresh waters of the Earth hydrosphere as a whole makes: Co- 0.25 (margins of variation 0.04-8), $\mathrm{Pb}-1.0$ (0.06-120), Ni-2.5 (0.02-27) and $\mathrm{Cu}-7.0(0.2-30)$ $\mathrm{mkg} / \mathrm{L}[14,15]$. Comprised given numbers allow to ascertain that the river and lake waters of the discussed area are not polluted by heavy metals. According to the Figure 2 the most contribution to enrichment of the discussed category of waters is made by the following heavy metals: copper on the average $64.2 \%$ (varying 45.9-82.2\%), nickel 19,6\% (6.8-41.1), lead-14\% (3.7$26.7)$ and cobalt $-2.2 \%(0.7-4.1)$.

In waters of bog ecosystems related in geochemical coupling to subordinate landscapes the total concentration of heavy metals is visibly higher $-4.5-19.0 \mathrm{mkg} / \mathrm{L}$. Bog waters which characterize the natural background accumulate nickel 4,9 times, cobalt 2.4 times, copper 1,9 times more. As it follows from the Figure $\mathbf{2 b}$, the nickel contribution to enriching the water phase of bog ecosystems by heavy metals increases on the average up to $39,7 \%$ (varying makes 20.4-62.3). However, the leading role as before is played by copper $-51.6 \%$ (33.8-78.0). Lead contribution decreases visibly. Reaching the bog ecosystems it is evidently adsorbed by peat substrate independently of a source of coming.

The total concentration of heavy metals in polluted bog waters increases up to $145-800 \mathrm{mkg} / \mathrm{L}$. The exceeding order in relation to natural background of bogs makes: $\mathrm{Co}(64.4)>\mathrm{Ni}(48.9)>\mathrm{Cu}$ (35.3) $>\mathrm{Pb}$ (1.75). As before nickel and copper contribute mostly to pollution (Figure 2c). Therewith the nickel share in the total pollution by heavy metals becomes decisive and achieves on the average $57.5 \%$ (varying is $35.7-85.1$ ), Copper share is $39.8 \%$ (13.6-60.7). The role of cobalt and especially of lead is very small.

Assessment of water pollution level was realized according to the exceeding order (factor) of levels of maximum permissible concentration [16]. The exceeding order of norms was calculated by the formula:

$$
K_{i}=C_{i} / C_{M P C}
$$


Table 4. Heavy metal amount in surface waters of the north- siberian (Taimyr) lowland, mkg/l (the mean water phase).

\begin{tabular}{|c|c|c|c|c|c|c|c|c|c|}
\hline $\begin{array}{l}\text { № of } \\
\text { samples }\end{array}$ & $\mathrm{Ni}$ & $\mathrm{Cu}$ & $\mathrm{Co}$ & $\mathrm{Pb}$ & $\begin{array}{c}\text { № of } \\
\text { samples }\end{array}$ & $\mathrm{Ni}$ & $\mathrm{Cu}$ & Co & $\mathrm{Pb}$ \\
\hline \multicolumn{5}{|c|}{ Waters of rivers, lakes, waterfall } & \multicolumn{5}{|c|}{ Bog waters (continuation) } \\
\hline $1 r$ & 0,16 & 1,62 & $<0,01$ & 0,57 & $17 b$ & 3,43 & 8,53 & $<0,01$ & 0,35 \\
\hline $3 r$ & 0,99 & 2,69 & 0,27 & 0,52 & $18 b$ & 3,15 & 10,5 & 0,47 & $<0,10$ \\
\hline $4 r$ & 0,92 & 1,84 & $<0,01$ & 0,31 & $21 b$ & 4,21 & 4,28 & $<0,01$ & 0,59 \\
\hline $5 r$ & 1,10 & 6,46 & $<0,01$ & 0,29 & $22 b$ & 285,0 & 485,00 & 25,40 & 3,40 \\
\hline $19 r$ & 0,88 & 4,73 & $<0,01$ & 0,65 & $23 b$ & 6,79 & 10,90 & $<0,01$ & 0,87 \\
\hline $20 r$ & 2,24 & 7,02 & $<0,01$ & 1,19 & $24 b$ & 102,0 & 16,30 & 0,85 & 0,71 \\
\hline $28 r$ & 2,15 & 2,40 & $<0,01$ & 0,67 & $25 b$ & 259,0 & 229,00 & 4,63 & $<0,1$ \\
\hline $6 l$ & 0,28 & 1,24 & 0,29 & 0,66 & $26 b$ & 345,0 & 314,00 & 6,01 & $<0,1$ \\
\hline $15 w$ & 0,47 & 1,99 & $<0,01$ & 0,45 & $27 b$ & 293,0 & 158,00 & 19,00 & 0,48 \\
\hline \multicolumn{5}{|c|}{ Bog waters } & $29 b$ & 9,12 & 6,47 & $<0,01$ & 0,93 \\
\hline $2 b$ & 1,37 & 5,24 & $<0,01$ & $<0,1$ & $30 \mathrm{~b}$ & 85,60 & 55,50 & 6,01 & 1,22 \\
\hline $7 b$ & 2,96 & 3,96 & $<0,01$ & 0,82 & $31 b$ & 9,45 & 8,67 & $<0,01$ & 0,90 \\
\hline $8 b$ & 4,29 & 4,82 & $<0,01$ & 0,78 & $32 b$ & 6,14 & 5,17 & $<0,01$ & 1,32 \\
\hline $12 b$ & 8,36 & 9,44 & $<0,01$ & 0,86 & $33 b$ & 1,76 & 2,12 & $<0,01$ & 0,60 \\
\hline $13 b$ & 0,10 & 0,10 & $<0,01$ & $<0,10$ & $34 b$ & 5,27 & 7,28 & 0,96 & $<0,10$ \\
\hline $14 b$ & 1,40 & 2,42 & $<0,01$ & 0,44 & $35 b$ & 5,66 & 7,83 & 1,16 & 0,45 \\
\hline $16 b$ & 5,97 & 3,24 & $<0,01$ & 1,36 & & & & & \\
\hline
\end{tabular}

* Points of water sampling and indices of waters are given in the Table 1.

Table 5. Descriptive statistics* of heavy metal amount in surface waters of the North- Siberian(Taimyr) lowland (the mean water phase).

\begin{tabular}{|c|c|c|c|c|c|c|c|c|}
\hline Elements & $\mathrm{m}$ & $\mathrm{s}_{x}$ & $\min$ & $\max$ & $\mathrm{R}$ & $\mathrm{S}^{2}{ }_{x}$ & $\mathrm{~S}_{x}$ & $\mathrm{C}_{v}$ \\
\hline 1 & 2 & 3 & 4 & 5 & 6 & 7 & 8 & 9 \\
\hline \multicolumn{9}{|c|}{ Waters of rivers, lakes, waterfall, $\sum_{\mathrm{HM}}-2,5-10,4 \mathrm{mkg} / \mathrm{L}$} \\
\hline Co & 0,07 & 0,039 & 0,01 & 0,29 & 0,28 & 0,014 & 0,119 & 170 \\
\hline $\mathrm{Pb}$ & 0,59 & 0,089 & 0,29 & 1,19 & 0,9 & 0,071 & 0,266 & 45 \\
\hline $\mathrm{Ni}$ & 1,02 & 0,247 & 0,16 & 2,24 & 2,08 & 0,549 & 0,741 & 72 \\
\hline $\mathrm{Cu}$ & 3,33 & 0,726 & 1,24 & 7,02 & 5,78 & 4,744 & 2,178 & 65 \\
\hline \multicolumn{9}{|c|}{ Waters of peat bogs of natural background, $\sum_{\mathrm{HM}} * *-4,5-19,0 \mathrm{mkg} / \mathrm{L}$} \\
\hline Co & 0,16 & 0,087 & 0,01 & 1,16 & 1,15 & 0,128 & 0,358 & 223 \\
\hline $\mathrm{Pb}$ & 0,57 & 0,088 & 0,1 & 1,32 & 1,22 & 0,131 & 0,361 & 63 \\
\hline 1 & 2 & 3 & 4 & 5 & 6 & 7 & 8 & 9 \\
\hline $\mathrm{Ni}$ & 4,67 & 0,675 & 0,1 & 9,45 & 9,35 & 7,751 & 2,784 & 60 \\
\hline $\mathrm{Cu}$ & 5,94 & 0,755 & 0,1 & 10,9 & 10,8 & 9,685 & 3,112 & 52 \\
\hline \multicolumn{9}{|c|}{ Waters of peat bogs of technogenic pollution, $\sum_{\mathrm{HM}}-145-800 \mathrm{mkg} / \mathrm{L}$} \\
\hline Co & 10,31 & 3,924 & 0,85 & 25.4 & 24,55 & 92,392 & 9,612 & 93 \\
\hline $\mathrm{Pb}$ & 1,00 & 0,509 & 0,1 & 3.4 & 3,3 & 1,556 & 1,248 & 124 \\
\hline $\mathrm{Ni}$ & 228,27 & 44,075 & 85,6 & 345 & 259,4 & 11655,5 & 107,96 & 47 \\
\hline $\mathrm{Cu}$ & 209,63 & 70,92 & 16,3 & 485 & 468,7 & 30179 & 173,72 & 82 \\
\hline
\end{tabular}

*Legend: $\mathrm{m}$-mean, $\mathrm{mkg} / \mathrm{L}, \mathrm{s}_{x}$-error of the mean, min-minimum, max-maximum, $\mathrm{R}$-amplitude (range), $\mathrm{S}_{x}{ }_{x}$-dispersion, $\mathrm{S}_{x}-$ standard deviation, $\mathrm{C}_{v}-$ variation coefficient, ${ }^{* *} \sum_{\mathrm{HM}^{-}}-$sum of water soluble heavy metals. 


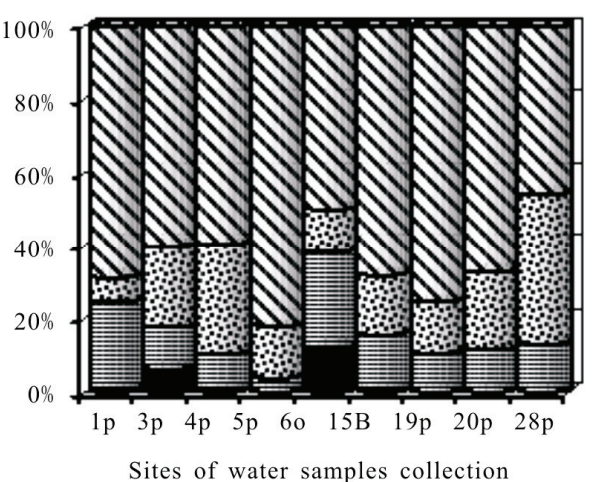

(a)

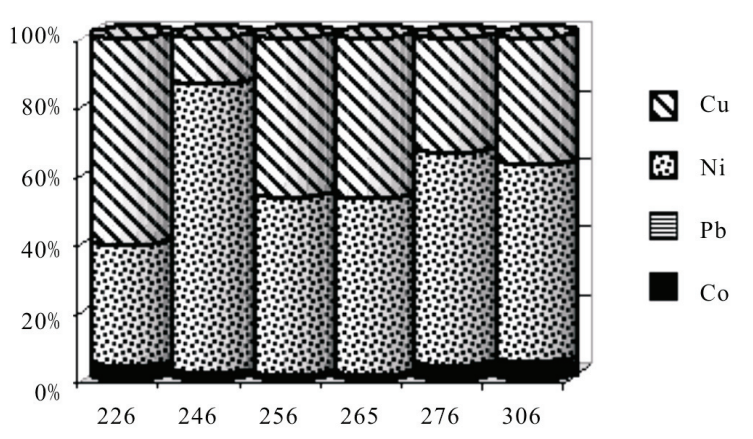

Sites of water samples collection

(c)

Figure 2. $\mathrm{Cu}, \mathrm{Ni}, \mathrm{Co}, \mathrm{Pb}$ contribution to enriching waters of rivers, lakes and waterfall (a), bog waters of natural background (b) and bog waters with signs of technogenic pollution (c). Captions (legends) and points of water sampling are in the Table 1.

where $\mathrm{K}_{\mathrm{i}}$-the exceeding order of maximum permissible concentration by i-ingredient; $\mathrm{C}_{\mathrm{i}}-$-concentration of $\mathrm{i}-$ ingredient in the water object, mkg/L; $\mathrm{C}_{\mathrm{MPC}}-$ maximum permissible concentration of $\mathrm{i}$-ingredient, $\mathrm{mkg} / \mathrm{L}$. If the exceeding makes not more than 2 units then the pollution level is considered to be low; $2-10$ it is middle, $10-50$ it is high, 50-100 units it is considered to be very high.

The MPC levels which are established for fresh drinkable water are the following: $\mathrm{Co}$ and $\mathrm{Ni}-100, \mathrm{Cu}-1000$,

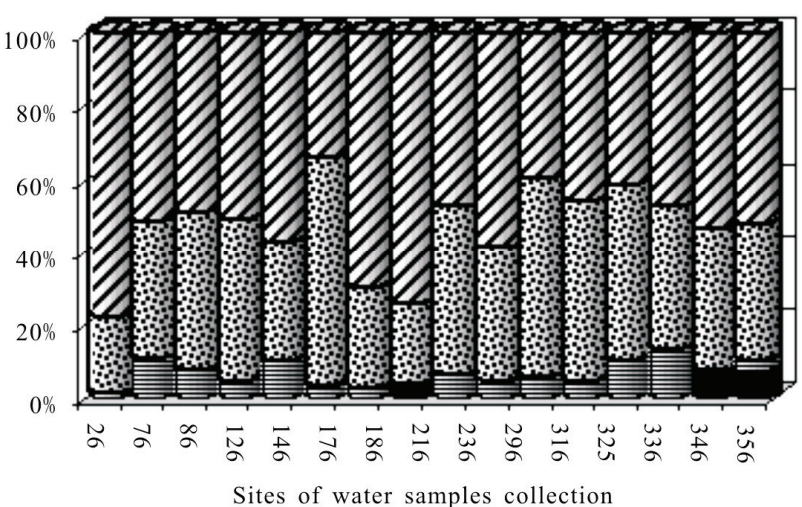

(b)

$\mathrm{Pb}-30-50 \mathrm{mkg} / \mathrm{L}$ [17]. As it follows from the given data (Tables 4 and 5) the waters of most bogs, rivers and lakes of Taimyr lowland are not polluted by heavy metals. Only in the lakes of large mound peatland Oganer with the highest copper and nickel amount (epicenter of technogenic emission) the MPC exceeding order of nickel is noted 2.6-3.4 times what shows an average pollution level of bog waters (Table 6).

\section{Conclusions}

1) Surface waters of eutrophic bogs (fens) in the NorthSiberian (Taimyr) lowland, like rivers and lakes of this area, relate to the group of cold weakly thermal and to the type of oxygen waters, mainly, to the class of neutral weakly alkaline and to the family of ultrafresh and fresh waters and to the kind of waters poor with dissolved or ganic matter. The hydrochemical background is presented by hydrocarbonate, sulfate as well as hydro carbonate-sulfate calcium-magnesium waters which show regional; specificity connected with deposits in depths of sulfide copper and nickel ores.

2) Sulfate waters are inherent only in bog ecosystems. In their alkaline- acidic properties they relate to different water classes and characterize indirectly the mechanisms of medium reaction. In our opinion, neutral and weakly alkaline waters reveal the subalkaline trend of the intrachamber differentiation of sulfide fields in the Norilsk

Table 6. Assessment of pollution level ${ }^{1}$ of bog waters in lakes of the large mound peatland (vicinity of Oganer suburb).

\begin{tabular}{|c|c|c|c|c|c|}
\hline \multirow{2}{*}{$\begin{array}{c}\mathrm{N} \text { of } \\
\text { sample }\end{array}$} & \multirow{2}{*}{ Location of lakes } & \multicolumn{2}{|c|}{ Nickel amount } & \multicolumn{2}{|c|}{ Copper amount } \\
\hline & & $\mathrm{K}^{2}$ & Level of pollution & $\mathrm{K}$ & Level of pollution \\
\hline \multirow[t]{2}{*}{$22 b$} & Peat mound with fire evidences & 2,8 & mean & 0,5 & not polluted \\
\hline & Height from a peatland foot: & & & & \\
\hline $25 b$ & $5 \mathrm{~m}$ & 2,6 & mean & 0,2 & not polluted \\
\hline $26 b$ & $10 \mathrm{~m}$ & 3,4 & mean & 0,3 & not polluted \\
\hline $27 b$ & $15 \mathrm{~m}$ & 2,9 & mean & 0,2 & not polluted \\
\hline
\end{tabular}

${ }^{1}$ according to: [16], ${ }^{2}$ Multiplicity of exceeding of a maximum concentration limit (MCL): Values of MCL are brought in the text. 
ore region. Acid sulfate bog waters related, as a rule, to vicinity of industrial complexes are formed most likely under technogenic fluxes of sulfur oxides. An active acidification of neutral and weakly alkaline hydrocarbonate (hydrocarbonate-sulfate) waters points to instability of aquatic phase of bogs to industrial emissions because of lack of mechanisms which support it in stable state (low mineralization, high dissolving ability, deficit of bases). Strongly alkaline sulfate-hydrocarbonate-sodium waters are connected with cryogenic processes and are formed in the result of interaction of waters with salinized mineral grounds which are cropped out owing to earthflow of melted peat thickness (solifluction).

3) Natural hydrochemical background of bog ecosystems makes in heavy metals in the first approximation: $\mathrm{Co}-0.16, \mathrm{~Pb}-0.57, \mathrm{Ni}-4.67$ and $\mathrm{Cu}-5.94 \mathrm{mkg} / \mathrm{L}$. In most cases the surface waters are not polluted by heavy metals: their migration in neutral and weakly alkaline waters is limited. As $\mathrm{Ni}, \mathrm{Cu}, \mathrm{Co}, \mathrm{Pb}$ increase in bog water composition, it appears the trend of increase of nickel contribution to the sum amount of heavy metals. Bog waters are polluted by nickel at mid-level when being located in immediate closeness from sources of industrial emissions.

\section{References}

[1] N. Y. Kats, "Bogs of the Globe," Nauka, Moscow, 1971, p. 295.

[2] N. I. P'yavchenko, “On Studying Bogs of Krasnoyarsk krai," In: "Paludified Forests and Bogs of Siberia", Press of the USSR Academy of Sciences, Moscow, 1963, pp. 532.

[3] "Middle Siberia," Nauka, Moscow, 1964, p. 480.

[4] O. A. Dyuzhikov, V. V. Distler, B. M. Strunin et al., "Geology and Ore-Bearing Capacity of Norilsk Region," Nauka, Moscow, 1988, p. 279.

[5] T. T. Taisaev, "Geochemistry of Taiga-Frozen Land- scapes and Searching the Ore Fields," Nauka, Novosibirsk, 1981, p. 136.

[6] "Standard Methods for Analyzing Water," Chemistry, Moscow, 1973, p. 376.

[7] Methodical Instructions, "Methodology for Performing Measurements of the Mass Sulfate Concentration in Waters Using The Titrimetric Method with Barium Salt," Rostov-na-Donu, 2006, p. 23.

[8] Methodical Instructions, "Methodology for Performing Measurements of the Mass Sodium and Potassium Concentration in Surface Waters of the Land Using the Flaming-Photometric Method," Rostov-na-Donu, 2008, p. 14.

[9] "Water Quality. Definition of Cobalt, Nickel, Copper, Zinc, Cadmium, Lead. Flaming Atomic and Absorption Spectro-Photometric Methods," p. 20.

[10] A. I. Perel'man and N. S. Kasimov, "Geochemistry of Landscape,” Astreya-2000 Press, Moscow, 1999, p. 768.

[11] S. P. Suslov, "Physical Geography of the USSR," Asian Part. State Education Pedagogical Press, Vol. II, Moscow, 1954, p. 711.

[12] O. A. Alekin, "General Hydrochemistry," Hydrometeo Press, Leningrad, 1948, p. 206.

[13] O. A. Alekin, "Essential Principles of Hydrochemistry," Hydrometeo Press, Leningrad, 1970, p. 444.

[14] V. V. Dobrovols'ky, "Essential Principles of Biogeochemistry," Higher School Press, Moscow, 1998, p. 413.

[15] H. J. M. Bowen, "Environmental Chemistry of the Elements," Academic Press, London, 1979, p. 333.

[16] V. P. Yemeliyanova, G. N. Danilova and T. K. Kolesnikova, "Assessment of Surface Water Quality of the Land in Hydrochemical Figures," Hydrochemical materials, Hydrometeo Press, Leningrad, Vol. 88, 1983, pp. 119-129.

[17] "Drinkable Water. Hygienic Specifications for Water Quality of Central Systems of Water Supply for Drinking: Sanitary Rules and Norms," Press Centre of the Russian Goskomsanepidemnadzor, Moscow, 1996, p. 111. 